\title{
Anurans of the Parque Estadual do Mirador, a remnant of Cerrado in the state of Maranhão, Northeastern Brazil
}

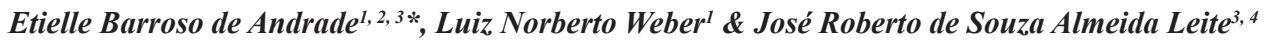 \\ ${ }^{1}$ Universidade Federal do Maranhão, Centro de Ciências Biológicas e da Saúde, Programa de Pós-Graduação em \\ Biodiversidade e Biotecnologia, Av. dos Portugueses, s/n, Campus do Bacanga, 65085-580, São Luís, MA, Brazil. \\ ${ }^{2}$ Instituto Federal de Educação, Ciência e Tecnologia do Piauí, Campus Paulistana, BR 407 s/n, Lagoa dos Canudos, \\ 64750-000, Paulistana, PI, Brazil. \\ ${ }^{3}$ Universidade Federal do Piauí, Núcleo de Pesquisa em Biodiversidade e Biotecnologia, Campus Parnaíba, \\ Av. São Sebastião 2819, 64202-020, Parnaíba, PI, Brazil. \\ ${ }^{4}$ Universidade de Brasília, Faculdade de Medicina, Área de Morfologia, Campus Universitário Darcy Ribeiro, \\ Asa Norte,70910-900, Brasilia, DF, Brazil. \\ *Corresponding author: Etielle Barroso de Andrade, e-mail: etlandrade@hotmail.com
}

ANDRADE, E. B., WEBER, L. N., LEITE, J. R. S. A. Anurans of the Parque Estadual do Mirador, a remnant of Cerrado in the state of Maranhão, Northeastern Brazil. Biota Neotropica. 17(4): e20160260. http://dx.doi. org/10.1590/1676-0611-BN-2016-0260

\begin{abstract}
The Cerrado is one of the most threatened biomes in Brazil. It is estimated that much of its original vegetation has been replaced by some type of human use. This is quite worrying, mainly in the northern part where the number of wildlife inventories is insufficient and creates the false impression of low diversity in the region. The Parque Estadual do Mirador-PEM, located in the south-central region of the state of Maranhão, presents vegetation typical of the Cerrado biome and corresponds to one of 46 priority areas for conservation in the state. Herein, we describe the species richness and composition of the anurofauna from the PEM and analyze the influence of different types of vegetation in its formation. Our inventory was conducted from December 2013 to February 2015, using the active search and auditory census methods on breeding sites in different water bodies of the park. We recorded 31 anuran species belonging to five families (species number in parentheses): Leptodactylidae (14), Hylidae (12), Bufonidae (3), Microhylidae (1) and Phyllomedusidae (1). The rarefaction curve and species richness estimators indicated that the sampling effort was enough to record most of the species in the region. The richness of anurans in the PEM was higher than reported by other authors for several areas of Cerrado. Most species have a wide distribution in Brazil or are strongly associated with the Caatinga or Amazon biomes. Only about 19\% are endemic to the Cerrado biome. This study is the first to inventory the anurans species of the south-central region of state of Maranhão and provides important data on amphibian communities from the northern part of the Brazilian Cerrado.
\end{abstract}

Keywords: inventory, Amphibia, Anura, conservation unit, species richness.

\section{Anfíbios anuros do Parque Estadual do Mirador, um remanescente de Cerrado no estado do Maranhão, nordeste do Brasil}

Resumo: O Cerrado é um dos biomas mais ameaçados do Brasil. Estima-se que grande parte da cobertura vegetal original deste bioma tenha sido substituída por alguma forma de utilização humana. Este fato é bastante preocupante, principalmente na porção norte, onde o número de inventários faunísticos é insuficiente e gera a falsa impressão de baixa diversidade na região. O Parque Estadual do Mirador-PEM, localizado na região centro-meridional do Maranhão, apresenta vegetação típica do Cerrado e corresponde a uma das 46 áreas prioritárias para conservação no estado. Aqui, nós descrevemos a riqueza e a composição da anurofauna no PEM, analisando a influência dos diferentes tipos vegetacionais na sua formação. Inventariamos a anurofauna de dezembro de 2013 a fevereiro de 2015, utilizando métodos de procura ativa e censo auditivo em sítios reprodutivos de diferentes corpos d'água do parque. Registramos 31 espécies de anuros, pertencentes a cinco famílias (números de espécies entre parênteses): Leptodactylidae (14), Hylidae (12), Bufonidae (3), Microhylidae (1) e Phyllomedusidae (1). A curva de rarefação e os estimadores de riqueza indicaram que o esforço amostral foi suficiente para registrar a maior parte das espécies da região. A riqueza de anuros no PEM foi maior que a registrada por outros autores em diversas áreas de Cerrado. A maioria das espécies possuem ampla distribuição no Brasil ou são fortemente associadas aos biomas Caatinga ou Amazônia. Somente cerca de 19\% são endêmicas do bioma Cerrado. O presente trabalho representa o primeiro estudo a inventariar as espécies de anfíbios anuros na região Centro-Sul do Maranhão e fornece dados importante sobre as comunidades de anfíbios da porção norte do Cerrado brasileiro.

Palavras-chave: inventário, Amphibia, Anura, unidade de conservação, riqueza de espécies. 


\section{Introduction}

The Cerrado is the second largest biome in Brazil, covering about a quarter of national territory, and extends from the state of Paraná to northern of the state of Maranhão (Ribeiro \& Walter 2008), including transition areas in the state of Piauí. Despite its great extension, it is believed that more than a half of the areas originally occupied by this biome have been lost in recent years due to uncontrolled human occupation and agribusiness expansion (Klink \& Machado 2005).

Except for Pampas biome, the Cerrado biome borders with all other Brazilian biomes, forming ecotonal areas of mutual influence. This mutual influence added to the historical, climatic and geomorphological processes (Silva \& Bates 2002) are responsible for the formation of a complex mosaic of phytophysionomies, ranging from open fields (fields or savannas) to forest formations (Ribeiro \& Walter 2008). These factors contribute to the formation of different types of microhabitats, allowing coexistence of species with different ecological niches, placing the Cerrado biome as holding $5 \%$ of the animals and plants in the world and accounting for about one third of Brazilian biodiversity (Brasil 2015). Furthermore, high rates of endemism and high level of threat make this biome one of 25 biodiversity hotspots for conservation priorities. Despite the global recognition of biological importance and conservation priorities of the Cerrado, conservation units protect only $9.4 \%$ of its area (IBAMA 2009) and at least 1173 species of animals are currently at extinction risk (MMA 2014).

The state of Maranhão has about $65 \%$ of its territorial extension covered by the Cerrado biome (IBGE 2004), which corresponds to almost $216,000 \mathrm{~km}^{2}$, and has one of the best-preserved Cerrado areas of the northern portion of the biome, being considered an important priority area for biodiversity conservation (Diniz-Filho et al. 2005b). The state has also large ecotone areas (transitions between Amazon-Cerrado formations and Cerrado-Caatinga) creating ecological corridors with high potential for species endemism (Barreto 2007, Silva et al. 2013), but that are rarely considered in environmental policy definitions. Furthermore, the Brazilian Ministry of the Environment (Ministério do Meio Ambiente), through Ordinance No. 09 from 27 January 2007, established actions for the implementation of priority areas for biodiversity conservation of the Brazilian biomes, and identified 46 priority areas for conservation in the state of Maranhão, 28 of them of extremely high priority (MMA 2007).

Although of great importance for biodiversity conservation, studies in the northern part of the Brazilian Cerrado regarding amphibian communities are still insufficient, mainly in the state of Maranhão (Barreto et al. 2007, Brasileiro et al. 2008, Andrade 2017), which creates a false impression of low species diversity in the region (Diniz-Filho et al. 2005a) The south-central portion of Maranhão, which encompasses the northern sector of the Cerrado biome, has large priority areas for faunal inventory (MMA 2007), especially by presenting knowledge gaps on various taxonomic groups, which further reinforces the need to obtain basic information about anuran fauna in the region. Moreover, this region is located in an important Brazilian ecotone, which suffer strong influence of the other biomes, as such Amazonia and Caatinga.

In this scenario, faunal inventories are important tools to collect information on the biology and species richness, providing basic requirements for development of ecological models necessary for the adoption of effective conservation measures (Gotelli \& Colwell 2001). Furthermore, the constant impact on amphibian populations caused by the intense anthropic activities in the Cerrado biome reinforces the need for taxonomic inventories (Ribeiro-Júnior \& Bertoluci 2009). Therefore, this study aims to inventory the anuran fauna of the Parque Estadual do Mirador-PEM, an important remnant of Cerrado environment in the northern portion of the Cerrado biome, Northeastern Brazil.

\section{Material and Methods}

\section{Study area}

The Parque Estadual do Mirador (PEM) is located in the central-meriodional region of the state of Maranhão (06 $10^{\circ}$ '- $06^{\circ} 42^{\prime}$ S and 44 $43^{\prime}-45^{\circ} 54^{\prime}$ W, 425 asl, WGS84 datum), Brazil, between the headwaters of the Itapecuru and Alpercartas rivers (Figure 1), and encompasses the municipalities of

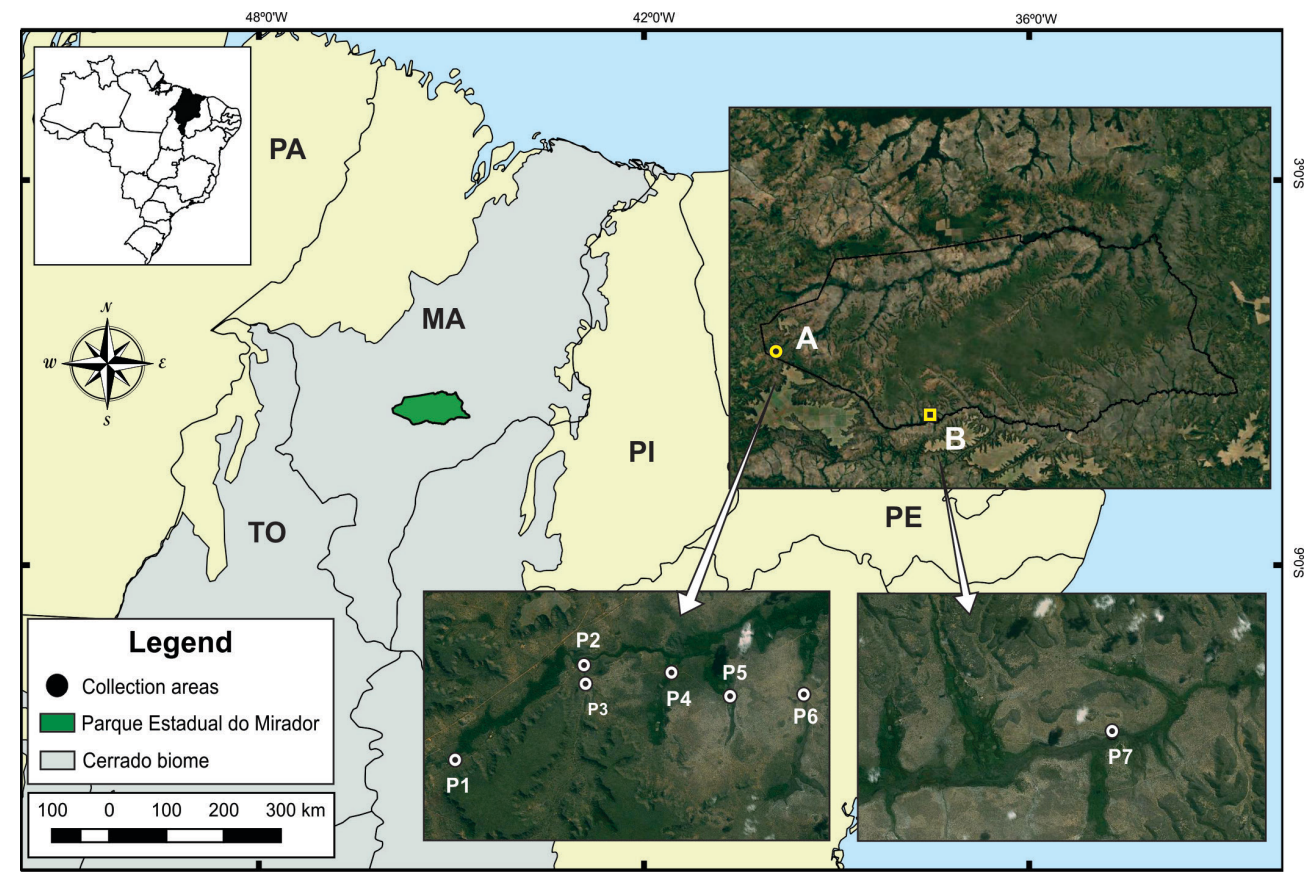

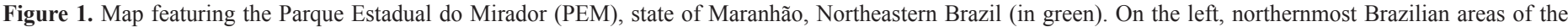

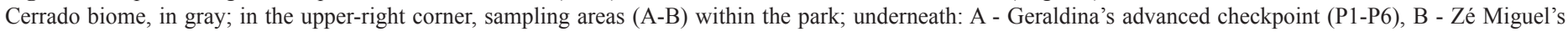
advanced checkpoint (P7). 
Mirador, Formosa da Serra Negra and Fernando Falcão. Created in 1980 by State Decree $n^{\circ} .641$ of June 20, the PEM has the Cerrado sensu lato as predominant vegetation (Conceição \& Castro 2009) on red-yellow latosols associated with quartz sands and lithic soils, stony and rocky. With an initial area of 700,000 ha, the PEM was expanded by Law $n^{\circ} .8 .958$ of May 8, 2009, having now a total area of 766,781.00 ha (Maranhão 2009). The climate is Aw' type (tropical sub-humid dry) with annual rainfall $1,200-1,400 \mathrm{~mm}$ and average temperatures ranging from $19.5^{\circ}$ to $33^{\circ} \mathrm{C}$ (Alcântara 2004).

We sampled seven points distributed between two areas. The area A (advanced monitoring station Geraldina) has six sampling points: P1 - permanent pond amidst the riparian forest; P2 - temporary pond with large amounts of aquatic vegetation inside; P3 - temporary pond in an open field; P4 - permanent stream in dirty field area with presence of spaced trees; P5 - permanent stream amidst the gallery forest; P6 - permanent stream in open area. The area B (advanced monitoring station Zé Miguel) has only one sampling point: P7 - swamp area, located near the banks of the Rio Itapecuru (see details in Table 1). The sampled sites presented different types of vegetation, varying from grasslands to areas of large trees and palm trees (Figure 2).

\section{Data collection}

Were conducted, bimonthly, eight field expeditions in each sampling area from December 2013 to February 2015, comprising both rainy and dry seasons. We used two sampling methods: active visual search and auditory census in different microhabitats used by frogs (Heyer et al. 1994). These methods are inexpensive and considered the most efficient to record the largest species number in the shortest time (Valdujo et al. 2009). Three researchers carried out field activities for three consecutive days, starting around 6 p.m and ending at 12 p.m, resulting in a sampling effort of 144 hours/person. Furthermore, opportunistic records of vocalizations, or individuals found outside sampling points, were included in the list of species.

Identification of specimens were carried out through vocalization and/or comparison with specimens housed at the Herpetological Collection of the Universidade Federal do Maranhão and Delta do Parnaíba Zoological Collection housed at the Universidade Federal do Piauí, Campus Parnaíba, Piauí, Brazil. Voucher specimens (Appendix 1) were collected under permit granted by "Secretaria de Estado do Meio Ambiente e Recursos Naturais do Maranhão" (SEMA-MA\#008/2013) and were deposited at the Delta do Parnaíba Zoological Collection (CZDP I1). No collected species is listed on the Brazilian list of Threatened Species (MMA 2014). The species distribution and taxonomic arrangement follow Frost (2017).

\section{Data analysis}

We evaluated the efficiency of anuran sampling methods in the PEM from using individual-based accumulation curves (Gotelli \& Colwell 2001). We calculated the expected species richness using the nonparametric estimators Jacknife 1 and Bootstrap (Magurran 2004). The analysis was performed in EstimateS software v.8.0.0 with 10,000 randomizations (Colwell 2006).

To compare the anuran species composition of PEM with studies performed in areas of Cerrado and in other biomes (Amazon, Atlantic Forest, Caatinga and Pantanal), we performed a hierarchical cluster analysis using the unweighted pair-group method with averaging (UPGMA) (Magurran 2004). This analysis optimizes intra-group homogeneity clustering the most similar samples (different localities) based on the species composition similarities (Silva et al. 2011). The studies were chosen randomly or according to the proximity to the PEM, and only six studies per biome were selected. Despite the disparities between types of environments and sampling methods generate difference in the anuran species composition (Pombal Jr. 1995), and the arbitrary chose of studies to insert a bias in our comparisons, the analysis was performed to demonstrate influence of other biomes on the anuran species composition of the PEM. We used the Jaccard similarity index (Magurran 2004) to construct the similarity matrix based in a presence and absence matrix with 328 anuran species. To reduce differences caused by taxonomic problems, we excluded from matrix the species without specific identification ("gr.", "aff." and "sp."), considering only species with identification to be confirmed ("cf."). The cluster analysis was performed on the software Past 3.06 (Hammer et al. 2001).

Data from anuran composition was taken from the following studies carried out in different regions of Brazil: Cerrado - Serra do Gado Bravo-SGB, Maranhão (Barreto et al. 2007), Tocantins river basin, southwestern Maranhão (Brasileiro et al. 2008), Parque Nacional das Emas-PNE, Goiás (Kopp et al. 2010), Estação Ecológica Serra Geral do Tocantins-EESGT, Tocantins and Bahia (Valdujo et al. 2011), Estação Ecológica Uruçuí-Una-EEUU, Piauí (Dal Vechio et al. 2013), Piracanjuba and Peixe river basins, southeastern Goiás (Santos et al. 2014); Caatinga - Boa Vista and São João do Cariri, Paraíba (Vieira et al. 2007), Planalto da Ibiapaba, Ceará (Loebmann \& Haddad 2010), Chapada do Araripe, Ceará (Ribeiro et al. 2012), Estação Ecológica Raso da Catarina-EERC, Bahia (Garda et al. 2013), Ilha Grande, Delta do Rio Parnaíba, Piauí (Andrade et al. 2014), Parque Nacional do Catimbau-PNC, Pernambuco (Pedrosa et al. 2014); Amazon - Reserva Ducke, Amazonas (Lima et al. 2005), Reserva Experimental Catuaba-REC, Acre (Souza et al. 2008), Altamira, Pará (Knispel \& Barros 2009), Rio Preto da Eva, Amazonas (Ilha \& Dixo 2010), Reserva Extrativista do Rio Gregório-RERG, Amazonas (Pantoja \& Fraga 2012), Querência, Mato Grosso

Table 1. Environmental description of the sampled habitats of the Parque Estadual do Mirador (PEM), south-central region of the state of Maranhão, Northeastern Brazil.

\begin{tabular}{|c|c|c|}
\hline Sampled habitats & Coordinates & Description \\
\hline P1 & $\begin{array}{l}6^{\circ} 37^{\prime} 49.60 ” \mathrm{~S} \\
45^{\circ} 52^{\prime} 44.00^{\prime \prime} \mathrm{W}\end{array}$ & $\begin{array}{l}\text { Large pond surrounded by medium to large trees and the presence of aquatic weeds and small islands formed by emergent } \\
\text { vegetation within the pond. }\end{array}$ \\
\hline $\mathrm{P} 2$ & $\begin{array}{l}6^{\circ} 36^{\prime} 10.6^{\prime \prime} \mathrm{S} \\
45^{\circ} 50^{\prime} 32.00^{\prime \prime} \mathrm{W}\end{array}$ & $\begin{array}{l}\text { Small pond surrounded by spaced vegetation, few trees and many herbaceous plants, with large amount of herbaceous } \\
\text { and aquatic vegetation within the water. }\end{array}$ \\
\hline $\mathrm{P} 3$ & $\begin{array}{c}6^{\circ} 36^{\prime} 27.65^{\prime \prime} \mathrm{S} \\
45^{\circ} 50^{\prime} 29.58^{\prime \prime} \mathrm{W}\end{array}$ & Pond formed in a flooded field, located in a spaced arboreal vegetation area, with little shrub vegetation inside. \\
\hline P4 & $\begin{array}{l}6^{\circ} 36^{\prime} 13.30^{\prime \prime} \mathrm{S} \\
45^{\circ} 49^{\prime} 1.50^{\prime \prime} \mathrm{W}\end{array}$ & $\begin{array}{l}\text { Stream located in a "campo sujo" (grassland with sparse shrubs) area. The marginal vegetation is shrub type with opened } \\
\text { areas and emergent vegetation. }\end{array}$ \\
\hline P5 & $\begin{array}{l}6^{\circ} 36^{\prime} 37.30 ” \mathrm{~S} \\
45^{\circ} 47^{\prime} 59.20^{\prime \prime} \mathrm{W}\end{array}$ & $\begin{array}{l}\text { Stream within the gallery forest, with the presence of large palm trees. It features flat edge and soaked in much of its } \\
\text { length and accumulation of leaf litter on the ground. }\end{array}$ \\
\hline P6 & $\begin{array}{c}6^{\circ} 36^{\prime} 34.20^{\prime \prime} \mathrm{S} \\
45^{\circ} 46^{\prime} 43.90^{\prime \prime} \mathrm{W}\end{array}$ & $\begin{array}{l}\text { Stream within an opened field area with the presence of some palm trees. The marginal vegetation is formed by herbaceous } \\
\text { plants. }\end{array}$ \\
\hline P7 & $\begin{array}{c}6^{\circ} 47^{\prime} 28.20^{\prime \prime} \mathrm{S} \\
45^{\circ} 28^{\prime} 25.10^{\prime \prime} \mathrm{W}\end{array}$ & $\begin{array}{l}\text { Flooded field formed periodically during the rainy season, presenting a large extension and covered by emergent vegetation } \\
\text { and few trees fairly spaced. }\end{array}$ \\
\hline
\end{tabular}



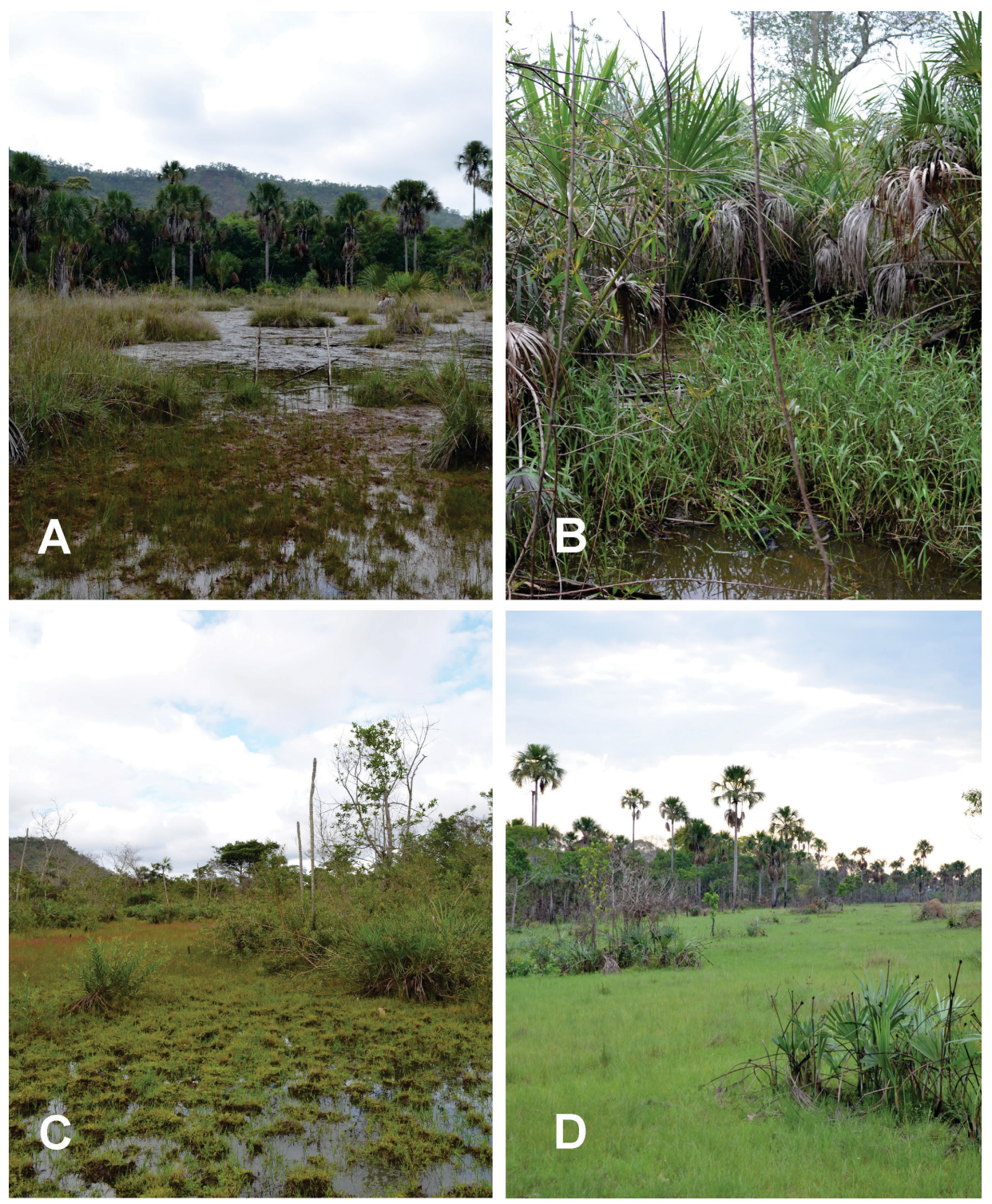

Figure 2. Sampled environments in the Parque Estadual do Mirador (PEM), state of Maranhão, Northeastern Brazil. Collection points: $A=P 1, B=P 2, C=P 3$, and D $=P 7$.

(Bitar et al. 2012); Atlantic Forest - Área de Preservação Permanente Mata do Buraquinho-APPMB, Paraíba (Santana et al. 2008), Reserva Ecológica Rio das Pedras-RERP, Rio de Janeiro (Carvalho-e-Silva et al. 2008), Serra do Ouro Branco-SOB, Minas Gerais (São Pedro \& Feio 2011), Parque Estadual Carlos Botelho-PECB, São Paulo (Forlani et al. 2010), Jequié, Bahia (Silva et al. 2013), Reserva de Serra Bonita-RSB, Bahia (Dias et al. 2014); Pantanal - Corumbá, Mato Groso do Sul (Ávila \& Ferreira 2004), Serras do Entorno do Pantanal Sul-SEPS, Mato Groso do Sul (Gordo \& Campos 2005), Estação Ecológica Nhumirim-EEN, Mato Grosso do Sul (Gordo \& Campos 2003), Parque Nacional da Serra da Bodoquena-PNSB, Mato Groso do Sul (Uetanabaro et al. 2007), Fazenda Baía da Pedra-FBP, Mato Grosso (Pansonato et al. 2011).

\section{Results and Discussion}

We recorded 31 species of anuran amphibians distributed in 11 genera and five families (species number in paretheses): Leptodactylidae (14), Hylidae (12), Bufonidae (3), Microhylidae (1) and Phyllomedusidae (1)
(Table 2; Figure 3-4). From this total, 29 species had their occurrence recorded from visual encounters and two species (Elachistocleis sp. and Boana boans) were only recorded through vocalization. Two species (Leptodactylus petersii and L. mystaceus) were visually observed outside the sampled points. Among the species recorded in the PEM, $80.6 \%(n=25)$ were considered as least concern (LC) according to IUCN Red List Categories and Criteria (IUCN 2012). The LC category includes generalist and abundant species not qualified in another category (Critically Endangered, Endangered, Vulnerable or Near Threatened) (IUCN 2012). Pseudopaludicola canga and P. jaredi present deficient data (DD) due the lack of appropriate informations on their abundances, distributions and ecological requirements (IUCN 2012). Conservation status was not provided for Dendropsophus sp., Scinax aff. ruber, Adenomera sp. and Elachistocleis sp. since they were not identified at the specific level (Table 2). Considering the individuals number, we recorded a total of 892 inividuals which Scinax fuscomarginatus $(\mathrm{n}=83 ; 9.30 \%)$, Boana multifasciata $(\mathrm{n}=76 ; 8.52 \%)$ and Dendropsophus rubicundulus $(\mathrm{n}=68 ; 7.62 \%)$ were 


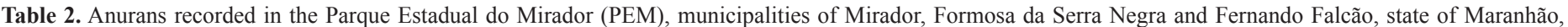

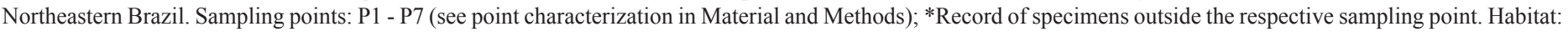

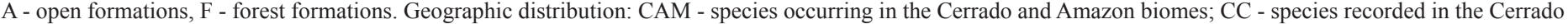

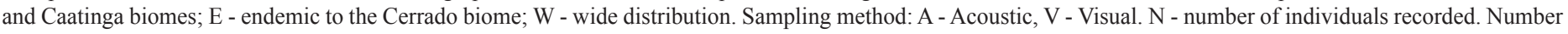
of species per family in parentheses. CS - Conservation status of the species classified according to IUCN: LC - least concern, DD - data deficient.

\begin{tabular}{|c|c|c|c|c|c|c|}
\hline Taxon & Samp. point & Habit. & Geogr. dist. & Samp. method & $\mathbf{N}$ & CS \\
\hline \multicolumn{7}{|l|}{ BUFONIDAE (3) } \\
\hline Rhinella jimi (Stevaux, 2002) & P1, P5, P6 & A & $\mathrm{CC}$ & $\mathrm{A} / \mathrm{V}$ & 7 & $\mathrm{LC}$ \\
\hline Rhinella mirandaribeiroi (Gallardo, 1965) & $\mathrm{P} 2 *, \mathrm{P} 6$ & A & $\mathrm{CC}$ & $\mathrm{A} / \mathrm{V}$ & 13 & $\mathrm{LC}$ \\
\hline Rhinella ocellata (Günther, 1858) & P2 & A & $\mathrm{E}$ & $\mathrm{A} / \mathrm{V}$ & 4 & $\mathrm{LC}$ \\
\hline \multicolumn{7}{|l|}{ HYLIDAE (12) } \\
\hline Dendropsophus branneri (Cochran, 1948) & $\mathrm{P} 1, \mathrm{P} 2$ & $\mathrm{~F}$ & W & $\mathrm{A} / \mathrm{V}$ & 48 & $\mathrm{LC}$ \\
\hline Dendropsophus minutus (Peters, 1872) & P1-P3 & A & W & $\mathrm{A} / \mathrm{V}$ & 56 & $\mathrm{LC}$ \\
\hline Dendropsophus rubicundulus (Reinhardt \& Lütken, 1862) & P2, P3, P5 & A & $\mathrm{CC}$ & $\mathrm{A} / \mathrm{V}$ & 68 & $\mathrm{LC}$ \\
\hline Dendropsophus soaresi (Caramaschi \& Jim, 1983) & P3, P5 & $\mathrm{F}$ & $\mathrm{CC}$ & $\mathrm{A} / \mathrm{V}$ & 56 & $\mathrm{LC}$ \\
\hline Dendropsophus sp. & $\mathrm{P} 1, \mathrm{P} 7 *$ & $\mathrm{~F}$ & - & $\mathrm{A} / \mathrm{V}$ & 12 & - \\
\hline Boana boans (Linnaeus, 1758) & $\mathrm{P} 2 *, \mathrm{P} 7$ & $\mathrm{~F}$ & CAM & A & 4 & $\mathrm{LC}$ \\
\hline Boana multifasciata (Günther, 1859) & $\mathrm{P} 1, \mathrm{P} 2, \mathrm{P} 4-\mathrm{P} 7$ & $\mathrm{~A} / \mathrm{F}$ & CAM & $\mathrm{A} / \mathrm{V}$ & 76 & $\mathrm{LC}$ \\
\hline Boana punctata (Schneider, 1799) & $\mathrm{P} 1, \mathrm{P} 2, \mathrm{P} 4-\mathrm{P} 7 *$ & $\mathrm{~A} / \mathrm{F}$ & W & $\mathrm{A} / \mathrm{V}$ & 50 & $\mathrm{LC}$ \\
\hline Osteocephalus taurinus Steindachner, 1862 & P1, P5 & $\mathrm{F}$ & CAM & $\mathrm{A} / \mathrm{V}$ & 14 & $\mathrm{LC}$ \\
\hline Scinax fuscomarginatus (Lutz, 1925) & P1-P3 & A & W & $\mathrm{A} / \mathrm{V}$ & 83 & $\mathrm{LC}$ \\
\hline Scinax nebulosus (Spix, 1824) & P1, P2, P4-P6 & $\mathrm{A} / \mathrm{F}$ & CAM & $\mathrm{A} / \mathrm{V}$ & 30 & $\mathrm{LC}$ \\
\hline Scinax aff. ruber & P3, P5, P7 & A & - & $\mathrm{A} / \mathrm{V}$ & 55 & - \\
\hline \multicolumn{7}{|l|}{ LEPTODACTYLIDAE (14) } \\
\hline Adenomera hylaedactyla (Cope, 1868) & $\mathrm{P} 2, \mathrm{P} 3, \mathrm{P} 6$ & $\mathrm{~A} / \mathrm{F}$ & CAM & $\mathrm{A} / \mathrm{V}$ & 10 & $\mathrm{LC}$ \\
\hline Adenomera saci Carvalho \& Giaretta, 2013 & P7 & A & E & $\mathrm{A} / \mathrm{V}$ & 41 & $\mathrm{LC}$ \\
\hline Adenomera sp. & $\mathrm{P} 1 *, \mathrm{P} 6, \mathrm{P} 7$ & A & - & $\mathrm{A} / \mathrm{V}$ & 4 & - \\
\hline Leptodactylus fuscus (Schneider, 1799) & P2-P5 & A & W & $\mathrm{A} / \mathrm{V}$ & 34 & $\mathrm{LC}$ \\
\hline Leptodactylus mystaceus (Spix, 1824) & $\mathrm{P} 1 *$ & - & W & V & 1 & $\mathrm{LC}$ \\
\hline Leptodactylus petersii (Steindachner, 1864) & P5 & & CAM & $\mathrm{V}$ & 2 & $\mathrm{LC}$ \\
\hline Leptodactylus sertanejo Giaretta \& Costa, 2007 & P7 & A & E & $\mathrm{A} / \mathrm{V}$ & 31 & $\mathrm{LC}$ \\
\hline Leptodactylus troglodytes Lutz, 1926 & P3 & A & $\mathrm{CC}$ & $\mathrm{A} / \mathrm{V}$ & 2 & $\mathrm{LC}$ \\
\hline Leptodactylus vastus Lutz, 1930 & P3, P5 & A & $\mathrm{CC}$ & V & 3 & $\mathrm{LC}$ \\
\hline Physalaemus centralis Bokermann, 1962 & P3, P6 & A & $\mathrm{E}$ & $\mathrm{A} / \mathrm{V}$ & 29 & $\mathrm{LC}$ \\
\hline Physalaemus cuvieri Fitzinger, 1826 & P3, P5 & A & W & $\mathrm{A} / \mathrm{V}$ & 31 & $\mathrm{LC}$ \\
\hline Pseudopaludicola canga Giaretta \& Kokubum, 2003 & $\mathrm{P} 1, \mathrm{P} 2, \mathrm{P} 5, \mathrm{P} 7$ & A & CAM & $\mathrm{A} / \mathrm{V}$ & 51 & DD \\
\hline $\begin{array}{l}\text { Pseudopaludicola jaredi Andrade, Magalhães, Nunes-de-Almeida, } \\
\text { Veiga-Menoncello, Santana, Garda, Loebmann, Recco-Pimentel, } \\
\text { Giaretta \& Toledo, } 2016\end{array}$ & P7 & A & $\mathrm{E}$ & $\mathrm{A} / \mathrm{V}$ & 8 & DD \\
\hline Pseudopaludicola mystacalis (Cope, 1887) & $\mathrm{P} 1, \mathrm{P} 3, \mathrm{P} 5$ & A & W & $\mathrm{A} / \mathrm{V}$ & 37 & $\mathrm{LC}$ \\
\hline \multicolumn{7}{|l|}{ MICROHYLIDAE (1) } \\
\hline Elachistocleis sp. & $\mathrm{P} 5, \mathrm{P} 7$ & A & - & $\mathrm{A}$ & 7 & - \\
\hline \multicolumn{7}{|l|}{ PHYLLOMEDUSIDAE (1) } \\
\hline Pithecopus azureus (Cope, 1862) & $\mathrm{P} 1 *-\mathrm{P} 5$ & $\mathrm{~A} / \mathrm{F}$ & $\mathrm{E}$ & $\mathrm{A} / \mathrm{V}$ & 24 & $\mathrm{LC}$ \\
\hline
\end{tabular}

the most abundant species, accounting for $25.45 \%$ of the total number of sampled individuals (Figure 5).

Out of 31 recorded species, $19.3 \%$ are endemic to Cerrado, $29 \%$ are distributed in at least one of the other biomes, mainly in the Caatinga and Amazon biomes, and $41.9 \%$ of them have wide distribution in Brazil (Valdujo et al. 2011, Frost 2017). All species have previous records for the state of Maranhão. Recently, three endemic species of the Cerrado hitherto unrecorded for the state had their geographical distributions extended until the limits of the PEM: A. saci (Araújo et al. 2015), L. sertanejo (Lima et al. 2015) and P. jaredi (Andrade et al. 2016a). We recorded these species calling under dense vegetation in a flooded field covered by emergent vegetation, located near the banks of the Rio Itapecuru, within a typical Cerrado area (sampling point P7). Pseudopaludicola jared $i$ was recently described, being currently recognized three isolated populations in the states of Ceará, Rio Grande do Norte and Maranhão (Andrade et al. 2016a, b), occurring syntopically with $P$. canga in the PEM (Andrade et al. 2016a). In this case, the development of studies to access the actual distribution and conservation status of this species is important.

The anuran fauna of the PEM consists for the most part by species typical of open formations (Cerrado-Caatinga-Chaco complex) and often found in the Cerrado biome (Valdujo et al. 2011, Frost 2017). Our results support other studies conducted in Cerrado areas (Brasileiro et al. 2008, Oda et al. 2009, Roberto et al. 2013, Dal Vechio et al. 2013, Santoro \& Brandão 2014, Dória et al. 2015), which affirm that the amphibian communities are dominanted by tolerant and generalist species. However, we recorded also typical species of forested areas, as Osteocephalus taurinus and $B$. boans, common species in riparian forests of the Cerrado and the Amazon biomes (Lima et al. 2005, Jungfer et al. 2013, Matavelli et al. 2013, Freitas et al. 2017). Boana boans was restricted to the Amazon Basin, but Matavelli et al. (2013) recorded the first occurrence of this species 

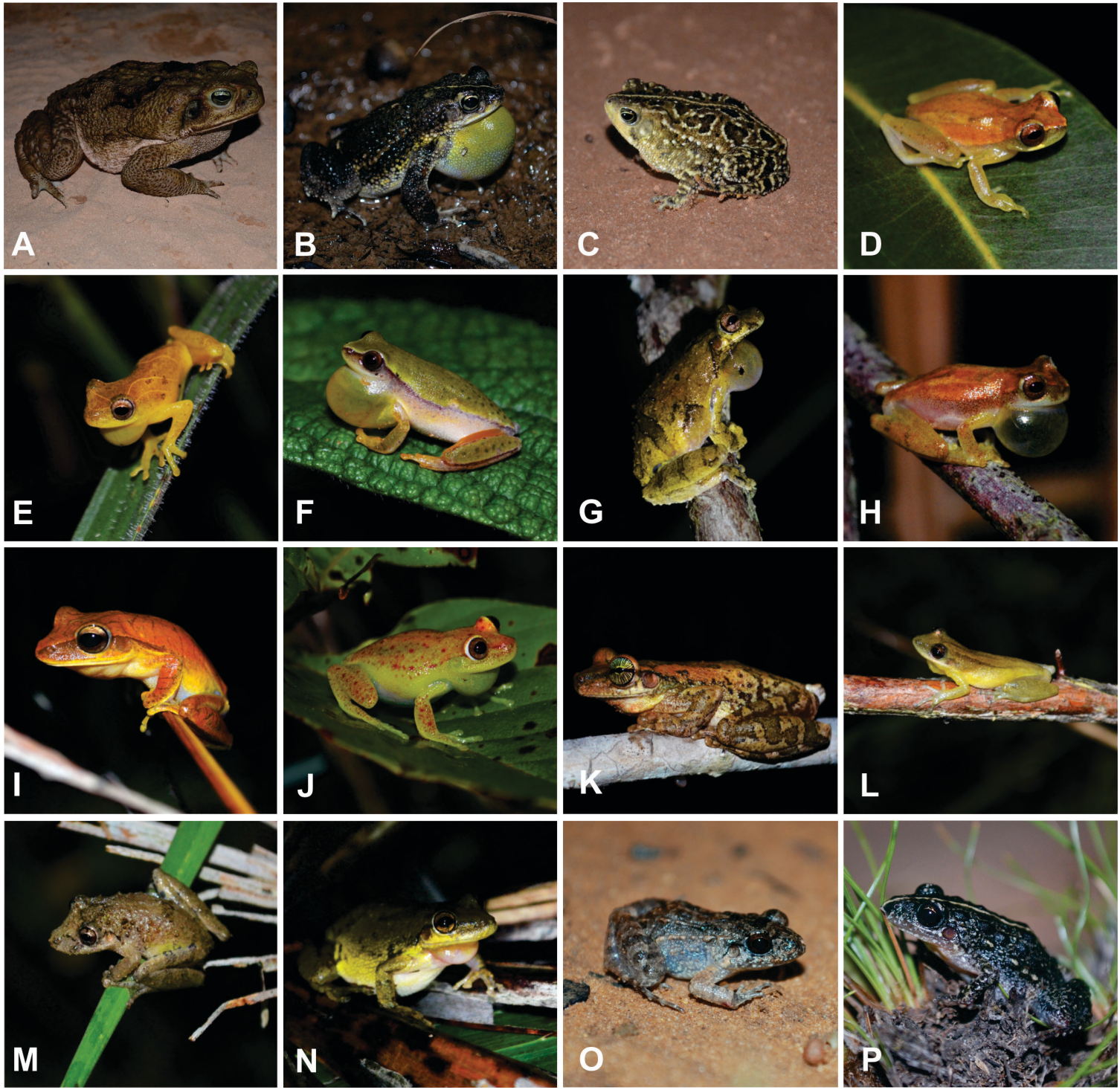

Figure 3. Anurans recorded in the Parque Estadual do Mirador (PEM), state of Maranhão, Northeastern Brazil. In parentheses, the institutional registration number and the specimen snout-vent length (SVL) for each vouchered specimen. A - Rhinella jimi (unvouchered specimen); B - R. mirandaribeiroi (CZDP I1 520; SVL 55.63 mm); C - R. occelata (CZDP I1 521; 40.70 mm); D - Dendropsophus braneri (CZDP I1 604; SVL 16.46 mm); E - D. minutus (CZDP I1 533; SVL 22.61 mm); F - D. rubicundulus (CZDP I1 535; SVL 21.65 mm); G - D. soaresi (CZDP I1 625; SVL 32.07 mm); H - Dendropsophus sp. (CZDP I1 607; SVL 19.97 mm); I - Boana multifasciata (CZDP I1 525; SVL $44.72 \mathrm{~mm}$ ); J - B. punctata (CZDP I1 529; SVL $29.79 \mathrm{~mm}$ ); K - Osteocephalus taurinus (CZDP I1 615; SVL 71.29 mm); L - Scinax fuscomarginatus (CZDP I1 532; SVL $22.76 \mathrm{~mm}$ ); M - S. nebulosus (CZDP I1 611; SVL $26.82 \mathrm{~mm}$ ); N - Scinax aff. ruber (CZDP I1 539; SVL $39.59 \mathrm{~mm}$ ); O - Adenomera hylaedactyla (CZDP I1-613; SVL 16.98 mm); P - A. saci (CZDP I1 456; SVL 23.05 mm).

in Cerrado areas in the state of Maranhão. Recently, Freitas et al. (2017) recorded the presence of this species in the REBIO Gurupi, a Biological Reserve of the Amazon biome in the northwestern Maranhão. We present here the third record of $B$. boans in the state of Maranhão, filling the distribution gap between the REBIO Gurupi region and the municipality of Mata Roma (Matavelli et al. 2013, Freitas et al. 2017). This indicates that this species has a wide distribution in forest areas in the Amazon and Cerrado biomes. In addition, we present the second record of Rhinella ocellata for the state of Maranhão, filling a distribution gap between its first occurrence in the northeast region of the state (Matavelli et al. 2014), and its closest record in the Estação Ecológica Uruçuí-Una, state of Piauí (Dal Vechio et al. 2013).

The accumulation curve presented a strong tendency towards stabilization (Figure 6), indicating that the methods used herein were effective to sample large part of the PEM species. Furthermore, according to the estimators used, it is expected the addition of only two species on observed richness (observed richness $=31 \pm 0.79$; Jacknife $1=33.95 \pm 1.67$; Bootstrap $=33.34$ ). The species richness of PEM was higher than that reported by other authors in different areas of the Brazilian Cerrado: Barreto et al. (2007; 23 spp.), Silva-Leite et al. (2008; 22 spp.), Oda et al. (2009; 29 spp.), Kopp et al. (2010; 25 spp.), Araujo \& Almeida-Santos (2011; 27 spp.), Dal Vechio et al. (2013; 26 spp.) and Dória et al. (2015; 22 spp.), and quite similar to the number of species observed by Valdujo et al. (2009; 32 spp.) in the municipality of São Desidério, Western Chapadão region of the state of Bahia (See Table 3 for comparison between the different localities of the Cerrado). Barreto et al. (2007) has reported the presence of only 23 frog species in a study on the anuran fauna of the Serra do Gado Bravo, River Basin Balsas, state of Maranhão, neighboring region to the PEM. 

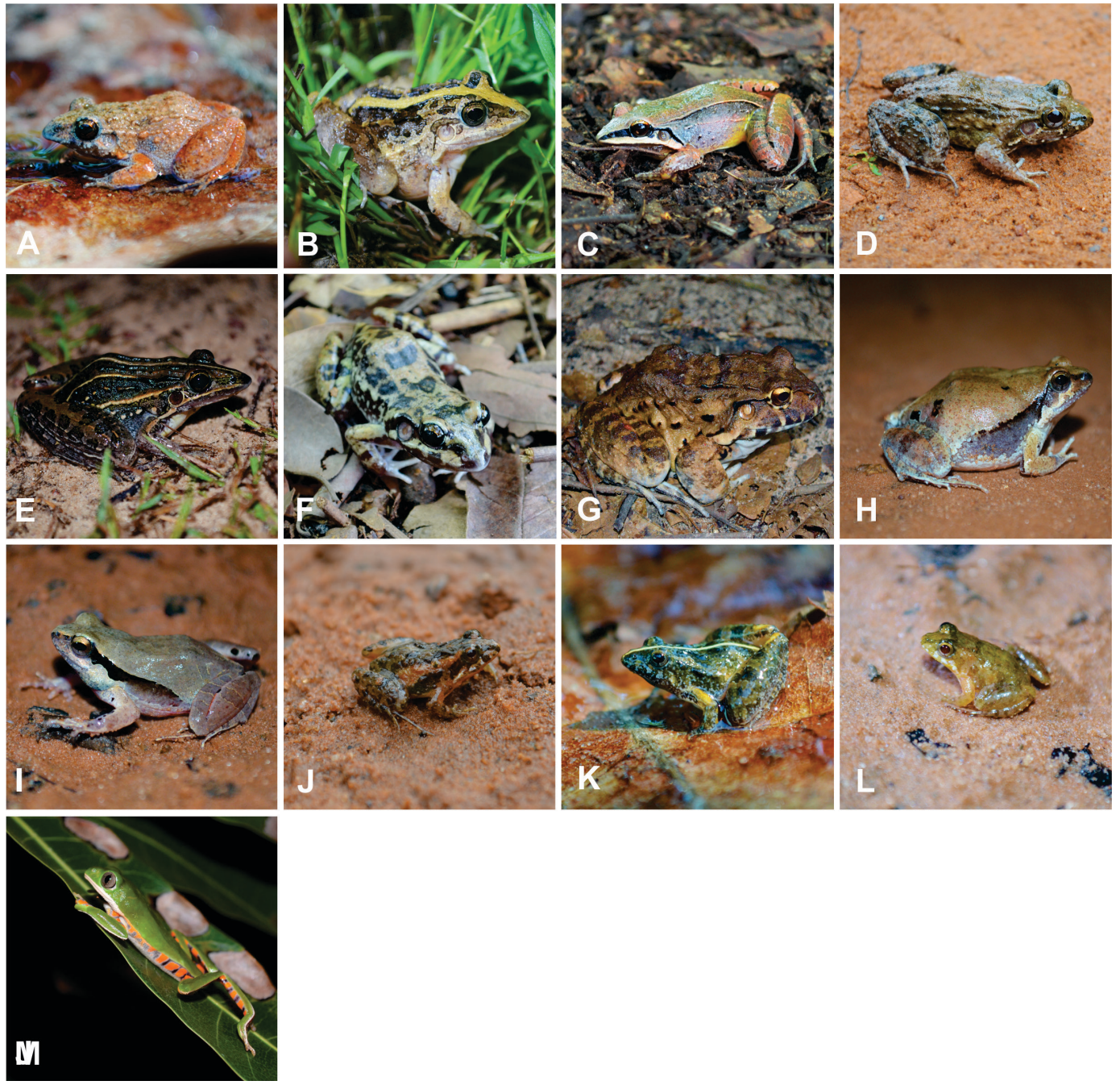

Figure 4. Anurans recorded in the Parque Estadual do Mirador (PEM), state of Maranhão, Northeastern Brazil. See caption of the figure 3 for additional information. A - Adenomera sp. (CZDP I1 537; SVL $18.42 \mathrm{~mm}$ ); B - Leptodactulus fuscus (CZDP I1 541; SVL 37.79 mm); C - L. mystaceus (CZDP I1 543; SVL 44.42 mm); D - L. petersii (CZDP I1 627; 42.88 mm); E - L. sertanejo (CZDP I1 544; 48.77 mm); F - L. troglodytes (CZDP I1 545; SVL 47.48 mm); G - L. vastus (CZDP I1 547; SVL 107.76 mm); H - Physalaemus centralis (CZDP I1 562; SVL 34.79 mm); I - P. cuvieri (CZDP I1 564; SVL 27.09 mm); J - Pseudopaludicola canga (CZDP I1 548; SVL $15.32 \mathrm{~mm}$ ); K - P. jaredi (CZDP I1 624; SVL 16.63 mm); L - P. mystacalis (CZDP I1 554; SVL 14.89 mm); M - Pithecopus azureus (CZDP I1 560; SVL 31.04 mm).

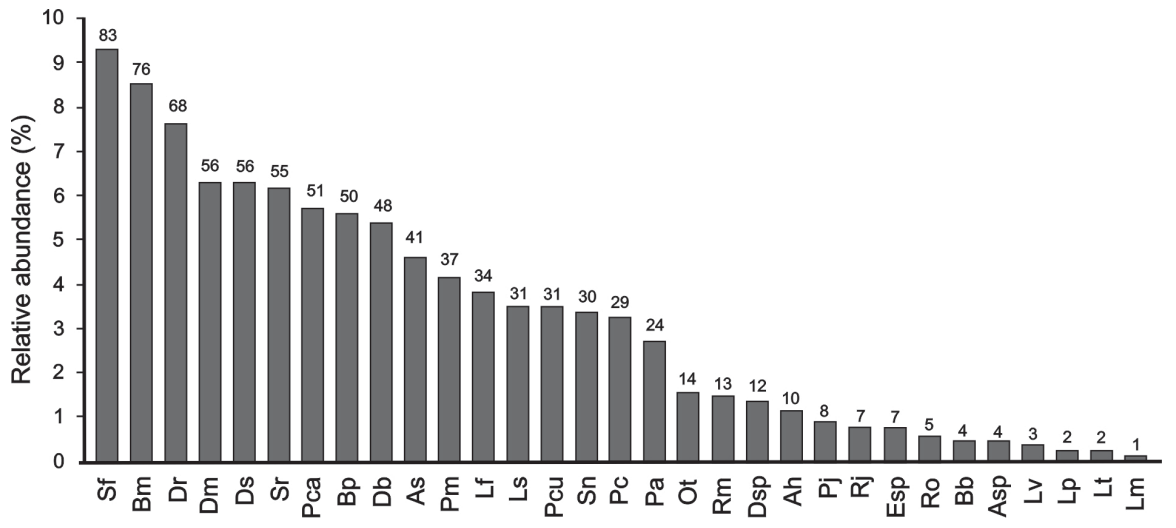

Figure 5. Relative abundance of anuran species in the Parque Estadual do Mirador (PEM), state of Maranhão, Northeastern Brazil. The total number of recorded individuals is indicated above each column. Anuran species: $\mathrm{Rj}$ - Rhinella jimi; $\mathrm{Rm}$ - R. mirandaribeiroi; Ro - R. occelata; Db - Dendropsophus braneri; Dm - D. minutus; Dr - D. rubicundulus; Ds - D. soaresi; Dsp - Dendropsophus sp.; Bb - Boana boans; Bm - B. multifasciata; Bp - B. punctata; Ot - Osteocephalus taurinus; Sf - Scinax fuscomarginatus; Sn - S. nebulosus; Sr - Scinax aff. ruber; Ah - Adenomera hylaedactyla; As - A. saci; Asp - Adenomera sp.; Lf - Leptodactulus fuscus; Lm - L. mystaceus; Lp - L. petersii; Ls - L. sertanejo; Lt - L. troglodytes; Lv - L. vastus; Pc - Physalaemus centralis; Pcu - P. cuvieri; Pca - Pseudopaludicola canga; Pj - P. jaredi; Pm - P. mystacalis; Esp - Elachistocleis sp.; Pa - Pithecopus azureus. 


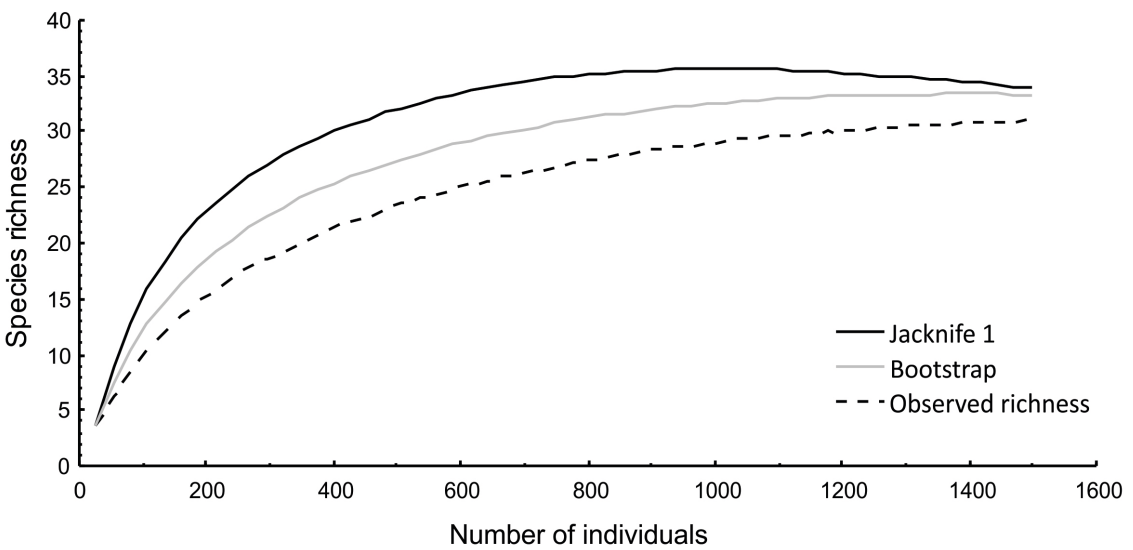

Figure 6. Accumulation curves for anurans sampled in the Parque Estadual do Mirador (PEM), state of Maranhão, Northeastern Brazil, based on the number of individuals representing the observed (Sobs) and estimated species richness (Bootstrap and Jacknife 1). Curves constructed from 10,000 randomizations.

Table 3. Localities with amphibian inventories in the Cerrado biome, including the Parque Estadual do Mirador (PEM). Spp. - Number of species; SE - sampling effort (days/month); NS - number of sampling sites; SM - sampling method (1 - interception and pitfall traps, 2 - sampling in breeding site; 3 - active search; 4 - casual encounter); DP - distance in kilometers from PEM.

\begin{tabular}{|c|c|c|c|c|c|c|}
\hline Localities & Spp. & $\begin{array}{c}\mathrm{SE} \\
\text { (days/month) }\end{array}$ & NS & SM & $\begin{array}{c}\text { DP } \\
(\mathbf{K m})\end{array}$ & Reference \\
\hline Balsas-MA & 23 & $40 / 4$ & 8 & 1,3 & 125 & Barreto et al. (2007) \\
\hline Parque Estadual de Terra-Ronca-GO & 22 & $-/ 12$ & 4 & 3 & 780 & Silva-Leite et al. (2008) \\
\hline Ingazeira Farm-BA & 22 & $30 / 4$ & 10 & 1,3 & 470 & Dória et al. (2015) \\
\hline Parque Nacional das Emas-GO & 25 & $-/ 16$ & 12 & 2 & 1500 & Kopp et al. (2010) \\
\hline Estação Ecológica Uruçuí-Una-PI & 26 & $66 / 4$ & 12 & $1,3,4$ & 280 & Dal Vechio et al. (2013) \\
\hline Estação Ecológica de Assis-SP & 27 & $35 / 7$ & 13 & $1,2,3,4$ & 1820 & Araujo \& Almeida-Santos (2011) \\
\hline Municipality of Niquelândia-GO & 29 & $36 / 12$ & 14 & $1,2,3$ & 870 & Oda et al. (2009) \\
\hline Parque Estadual do Mirador-MA & 31 & $24 / 8$ & 7 & $2,3,4$ & - & Present study \\
\hline São Desidério-BA & 32 & $12 / 2$ & 4 & 2,3 & 630 & Valdujo et al. (2009) \\
\hline Southeast of Maranhão & 33 & $28 / 4$ & 11 & $1,2,3,4$ & 220 & Brasileiro et al. (2008) \\
\hline Estação Ecológica Nova Roma-GO & 36 & $20 / 7$ & 8 & 1,3 & 800 & Campos \& Lage (2014) \\
\hline $\begin{array}{l}\text { Estação Ecológica Serra Geral do } \\
\text { Tocantins-TO/BA }\end{array}$ & 37 & $20 / 3$ & 8 & $1,2,3$ & 540 & Valdujo et al. (2011) \\
\hline Barro Alto-GO & 39 & $151 / 24$ & 5 & 2,3 & 985 & Gambale et al. (2014) \\
\hline
\end{tabular}

Even in other environmental protected areas, the species richness was lower than that observed in this study, such as the studies carried out in the Parque Estadual Terra Ronca, state of the Goiás (Silva-Leite et al. 2008), in the Parque Nacional da Emas, state of Goiás (Kopp et al. 2010) and in the Estação Ecológica Uruçuí-Una, state of Piauí (Dal Vechio et al. 2013), in which were recorded 22, 25 and 26 amphibian species, respectively. Our results support the idea that the low anuran diversity of the northern Cerrado biome reflects the small number of studies in these areas (Diniz-Filho et al. 2004, 2005a; Valdujo et al. 2011). In addition, it is evident the importance of PEM in terms of anuran diversity if compared to other areas of the Brazilian Cerrado.

On the other hand, increasing the sampled areas the number of species tends to increase, as observed by Brasileiro et al. (2008) and Melo et al. (2013), which recorded 33 and 36 species, respectively, in studies carried out in various sampling sites in the states of Maranhão and Goiás. Santos et al. (2014) registered 40 species of amphibians in 17 municipalities of the Piracanjuba and Peixe rivers basins in the southeast of Goiás. In the same way, long-term studies conducted to detect small spatio-temporal variations in the species composition between environments of a same region enable the registration of a greater species number and allows determining the actual species richness in the sampled environments (Valdujo et al. 2011,
Gambale et al. 2014). In addition, the use of several collection methods is critical to ensure the registration of species with different reproductive behaviors and/or different habits (terrestrial vs. arboreal vs. aquatic habits).

By studying the anuran fauna of underexplored areas, it is possible to find new species occurrences or even new species. Furthermore, it is usual to record species with taxonomic problems, such as the species of the genus Scinax. In the PEM, we recognized at least two species populations closely related to $S$. ruber, but to prevent future taxonomic problems, we adopted here a more conservative position recognizing them only as Scinax aff. ruber, as adopted by other authors (e.g. Valdujo et al. 2011, Dal Vechio et al. 2013, Roberto et al. 2013, Andrade et al. 2014). Similarly, acoustic differences between species of the genus Elachistocleis are almost undetectable to human ear, which prevented the identification of the species from this genus in the PEM because they were recorded only by their vocalizations and because there is the possibility that occur at least three species in region: E. piauiensis, E. carvalhoi and E. bumbameuboi (Caramaschi 2010). Furthermore, we believe that Dendropsophus sp. and Adenomera sp. are still undescribed species, being this latter morphologically similar to population samples obtained in several areas of the Cerrado and Caatinga biomes (e.g., Loebmann \& Haddad 2010, Dal Vechio et al. 2013, Roberto et al. 2013). 
Cluster analysis evidenced differences in species composition between the different biomes, revealing similarities lower than $30 \%$ in most of the comparisions (Figure 7). Despite the anuran community of PEM be composed also by species occurring in other types of environments, we observed the grouping of studies carried out in the Cerrado biome. The anuran species composition of the PEM presented a greater similarity with the study conducted in the Estação Ecológica Uruçuí-Una-EEUU (Dal Vecchio et al. 2013), located about $250 \mathrm{~km}$ in the southwest Piauí, and to the study conducted in Serra do Gado Bravo, located about $125 \mathrm{~km}$ in municipality of Balsas, southern state of Maranhão. Out of 26 species of anurans recorded in the EEUU, about 60\% (16 species) (D. minutus, D. rubicundulus, D. soaresi, B. multifasciata, O. taurinus, Pithecopus azureus, S. fuscomarginatus, L. fuscus, L. petersii, L. troglodytes, L. vastus, Physalaemus centralis, P. cuvieri, R. jimi, R. mirandaribeiroi and R. ocellata) were also common to the PEM. Six species (D. nanus, Trachycephalus typhonius, Rhaebo guttatus, R. veredas, Dermatonotus muelleri and E. carvalhoi) were exclusive to the EEUU. Out of 23 species recorded in the Serra do Gado Bravo, about 48\% (11 species) were also present in the PEM and in the EEUU (D. minutus, D. rubicundulus, B. multifasciata, L. fuscus, L. petersii, L. vastus, P. cuvieri, R. jimi, R. ocellata, R. mirandaribeiroi and P. azureus). Seven other species were exclusive to Serra do Gado Bravo
(R. margaritifera, B. albopunctata, B. raniceps, D. nanus, D. walfordi, Barycholos ternetzi and E. piauienseis).

Although this hypothesis has not been tested, we believe that the similarity pattern among the PEM, SGB and EEUU could be explained by biogeographic, historical and climatic factors that resulted in the formation of similar vegetation types (Colli et al. 2002). The three protected areas are located in high and steep areas of interfluvial, forming extensive gallery forests in drained areas (Conceição \& Castro 2009, Dal Vecchio et al. 2013 ) that allows displacement of species between patches of vegetation (Rodrigues 2005) favoring species composition similarity among these areas. Additionaly, the PEM presents several types of vegetation formations (typical cerrado, cerradão, veredas, dirty fields, flooded fields, open fields and riparian forests) and is inserted in the Uruçuí-Mirador biodiversity corridor, which can explain the great species richness and species composition. The Uruçuí-Mirador corridor, still in the implementation phase, has an estimated initial area of about 13.4 million hectares, distributed among the states of Piauí, Maranhão and Tocantins (Conceição \& Castro 2009, Dal Vecchio et al. 2013).

We also observed the occurrence of typical species from other biomes within the PEM, such as $B$. boans and $P$. canga (typical species of the Amazon biome), and L. troglodytes and L. vastus (typical species of

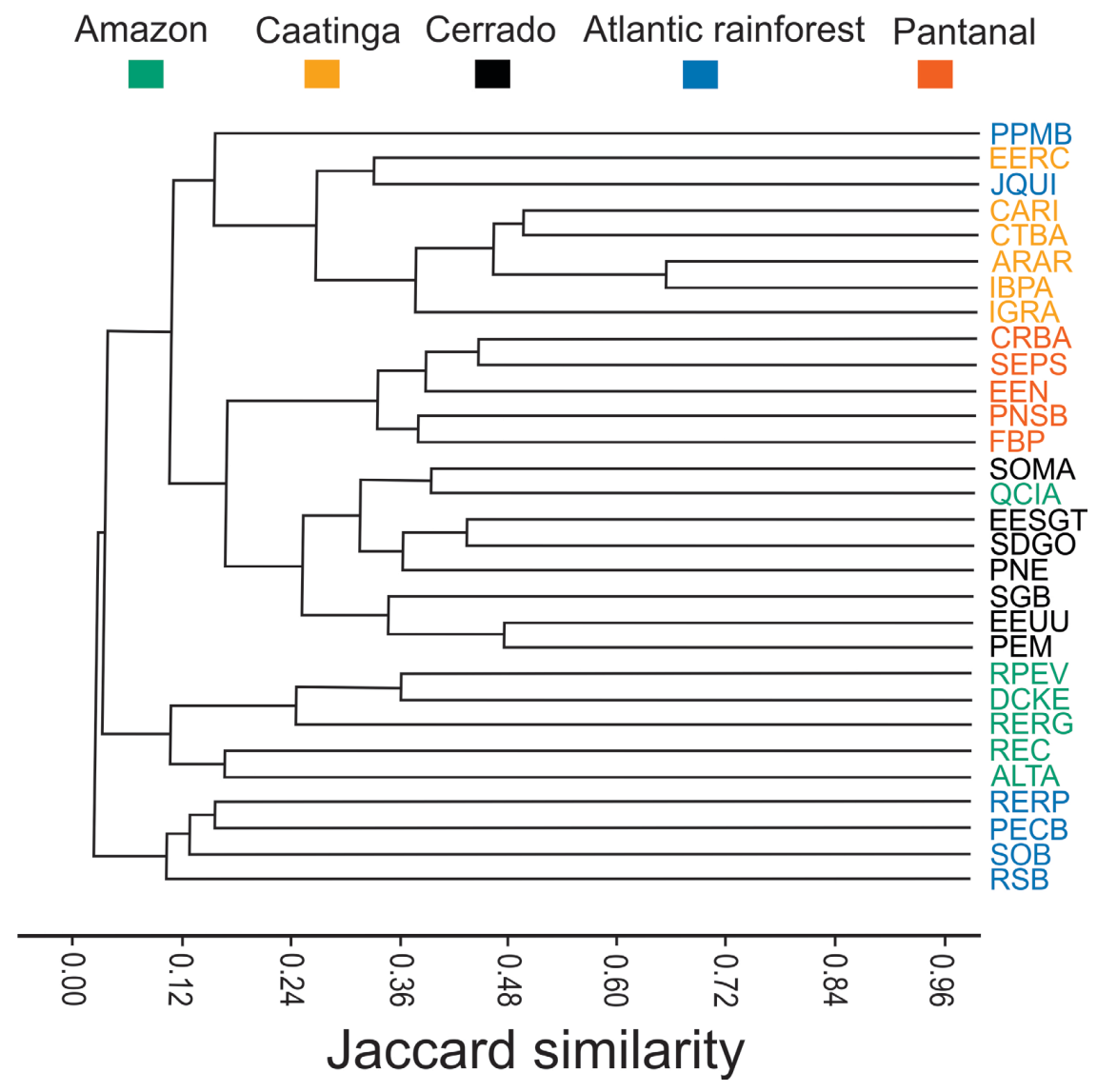

Figure 7. Similarity (Jaccard index and clustering method "UPGMA"; cophenetic correlation coefficient $=0.8841$ ) among the anuran species composition of the Parque Estadual do Mirador (PEM), state of Maranhão, Northeastern Brazil, and 24 Brazilian locaties distributed in the following biomes: Amazon (DCKE - Reserva Ducke; $R E C$ - Reserva Experimental Catuaba; $A L T A$ - Altamira; RPEV - Rio Preto da Eva; $R E R G$ - Reserva Extrativista do Rio Gregório; $Q C I A$ - Querência); Caatinga (CARI - Boa Vista e São João do Cariri; IBPA - Planalto da Ibiapaba; ARAR - Chapada do Araripe; EERC - Estação Ecológica Raso da Catarina; IGRA - Ilha Grande, Piauí; PNC - Parque Nacional do Catimbau); Cerrado (SOMA - Bacia do Rio Tocantins, Sudoeste do Maranhã; SGB - Serra do Gado Bravo; PNE - Parque Nacional das Emas; EESGT - Estação Ecológica Serra Geral do Tocantins; EEUU - Estação Ecológica Uruçuí-Una; SDGO - Bacia dos Rios Piracanjuba e Peixe, Sudeste de Goiás; $P E M$ - Parque Estadual do Mirador); Atlantic Forest (PPMB - Área de Preservação Permanente Mata do Buraquinho; RERP - Reserva Rio das Pedras; SOB - Serra do Ouro Branco; PECB - Parque Estadual Carlos Botelho; JQUI - Jequié; RSB - Reserva de Serra Bonita); and Pantanal (CRBA - Corumbá; SEPS - Serras de Entorno do Pantanal Sul; EEN - Estação Ecológica Nhumirim; PNSB - Parque Nacional da Serra da Bodoquena; FBP - Fazenda Baía de Pedra. 
the Caatinga biome). This pattern of species composition in the PEM is commonly observed in studies of anurans from the Cerrado biome (Uetanabaro et al. 2007, Brasileiro et al. 2008, Valdujo et al. 2009, 2011, Dal Vechio et al. 2013) and could be a result of its location in the region of Chapadas do Alto Itapecuru. This region receives the influence from elements of the Amazon and Caatinga biomes (e.g. vegetation, climate, hydrography, soil), which forms a mosaic of connected vegetation that enables a possible exchange of species between neighboring areas (Ganem 2007). In this case, PEM is located in a transition zone (humid vs. semiarid) and the spatial arrangement of habitat patches provides corridors for possible dispersal among the nearby wetlands (Maltchik et al. 2008).

Our research is one of the few studies to inventory the amphibians' species of south-central region of the state of Maranhão. It also provides important data about the amphibian communities of the PEM, which can contribute to implementation of management plan for the PEM and the for development of conservation measures of the amphibians' species in the northern part of the Brazilian Cerrado. Despite the observed species richness, we believed that the number of species is even greater, since the PEM has several not yet sampled environments and the methods adopted here do not include fossorial species registration or reproductive habits of the explosive type. Thus, there is a need to conduct future surveys to improve the knowledgement about the diversity and distribution of anurans in this important area in the Northeastern Brazil. In addition, further ecological studies are needed to understand the species richness pattern and the dynamics of PEM's amphibian populations, as these data are essential for the implementation of measures for species conservation. In fact, systematic studies on conservation planning are extremely urgent in the region, because of the threat imposed by agricultural expansion in the Cerrado biome that is replacing the natural floristic composition by large grain monoculture plantations, causing numerous environmental impacts and leading to the loss of regional biodiversity in the northern distribution of the Cerrado biome. Furthermore, the Parque Estadual do Mirador is an important bioregional corridor of preservation, which is crucial for the maintenancy of species diversity.

\section{Supplementary materia}

The following online material is available for this article:

Appendix 1 - Voucher specimens

\section{Acknowledgment}

We thank Thiago Ribeiro de Carvalho and Felipe Silva de Andrade for confirmation of the species identity. To Tássia Graziele Pires Lima, Micheli Véras dos Santos, Kássio de Castro Araújo, Johnny Sousa Ferreira and Sâmia Caroline Melo Araújo for helping in fieldwork. To Vinícius de Avelar São Pedro and Nivaldo Magalhães Piorski for suggestions and valuable contributions to improving the manuscript. We thank Secretaria de Estado de Meio Ambiente e Recursos Naturais-SEMA for providing collecting permit (008/2013), APERMIRA for permission to access to the Parque Estadual do Mirador and to Universidade Federal do Piauí-UFPI (Campus de Parnaíba) for logistical support. EBA thanks Fundação de Amparo à Pesquisa do Estado do Maranhão (FAPEMA) for financial support through the Support Program for Research Projects UNIVERSAL (edital $\mathrm{n}^{\circ}$ 001/2013 - FAPEMA) and Ph.D. grant (BD-01163/13).

\section{Author contributions}

Etielle Barroso de Andrade: contributed in data acquisition, analysis and interpretation of data, and writing of the paper.

Luiz Norberto Weber and José Roberto de Souza Almeida Leite: contributed in the conception and design of the paper and critical review adding intellectual content.

\section{Conflicts of interest}

The authors declare that they have no conflict of interest related to the publication of this manuscript.

\section{References}

ALCÂNTARA, E.H. 2004. Caracterização da bacia hidrográfica do rio Itapecuru, Maranhão-Brasil. Cam. Geogr. 7(11): 97-113.

ANDRADE, E.B. 2017. Padrões de diversidade e estruturação das comunidades de anfíbios anuros no Parque Estadual do Mirador-MA. 2017. 144 f., il. Tese (Doutorado em Biodiversidade e Biotecnologia) - Universidade Federal do Maranhão, São Luís.

ANDRADE, E.B., LEITE, J.R.S.A. \& ANDRADE, G.V. 2014. Anurans from the municipality of Ilha Grande, Parnaíba River Delta, Piauí, Northeastern Brazil. Herpetol. Notes. 7: 219-226.

ANDRADE, E.B., LIMA, T.G.P., ARAÚJO, K.C., LEITE, J.R.S.A \& WEBER, L.N. 2016a. Sympatric occurrence of two species of Pseudopaludicola (Anura: Leptodactylidae) and first record of Pseudopaludicola jaredi Andrade, Magalhães, Nunes-de-Almeida, Veiga-Menoncello, Santana, Garda, Loebmann, Recco-Pimentel, Giaretta \& Toledo, 2016 in the state of Maranhão, northeastern Brazil. Check List. 12(6): 2023.

ANDRADE, F.S., MAGALHÃES, F.M., NUNES-DE-ALMEIDA, C.H.L., VEIGAMENONCELLO, A.C.P., SANTANA, D.J., GARDA, A.A., LOEBMANN, D., RECCO-PIMENTEL, S.M., GIARETTA, A.A. \& TOLEDO, L.F. 2016b. A new species of long-legged Pseudopaludicola from northeastern Brazil (Anura, Leptodactylidae, Leiuperinae). Salamandra. 52(2): 107-124.

ARAUJO, C.O. \& ALMEIDA-SANTOS, S.M. 2011. Herpetofauna in a cerrado remnant in the state of Sao Paulo, Southeastern Brazil. Biota Neotrop. 11(3): $47-$ 62. http://www.biotaneotropica.org.br/v11n3/en/abstract? article+bn00511032011 (last access on 06/011/2017)

ARAÚJO, K.C., SANTOS, M.V., LIMA, T.G.P., ANDRADE, E.B. \& WEBER, L.N. 2015. First record of Adenomera saci Carvalho \& Giaretta, 2013 (Anura: Leptodactylidae) for the State of Maranhão, Northeastern Brazil. Herpetol. Notes. 8: 183-185.

ÁVILA, R.W. \& FERREIRA, V.L. 2004. Riqueza e densidade de vocalização de anuros (Amphibia) em uma área urbana de Corumbá, Mato Grosso do Sul, Brasil. Rev. Bras. Zool. 21(4): 887-892.

BARRETO, L. 2007. Cerrado Norte do Brasil - North Cerrado of Brazil. USEB, Pelotas.

BARRETO, L., ARZABE, C. \& LIMA, Y.C.C. 2007. Herpetofauna da região de Balsas. In Cerrado Norte do Brasil - North Cerrado of Brazil (L. Barreto, ed.) USEB, Pelotas, p.221-229.

BITAR, Y.O.C., PINHEIRO, L.P.C., ABE, P.S. \& SANTOS-COSTA, M.C. 2012 Species composition and reproductive modes of anurans from a transitional Amazonian forest, Brazil. Zool. 29(1): 19-26.

BRASIL. Ministério do Meio Ambiente. 2015. O Cerrado brasileiro. http://www mma.gov.br/biomas/cerrado (last access on 06/11/2017)

BRASILEIRO, C.A., LUCAS, E.M., OYAMAGUCHI, H.M., THOMÉ, M.T.C. \& DIXO, M. 2008. Anurans, northern Tocantins River Basin, states of Tocantins and Maranhão, Brazil. Check List. 4(2): 185-197.

CARAMASCHI, U. 2010. Notes on the taxonomic status of Elachistocleis ovalis (Schneider, 1799) and description of five new species of Elachistocleis Parker 1927 (Amphibia, Anura, Microhylidae). Bol. Mus. Nac., N.S., Zool. 527: 1-30.

CARVALHO-E-SILVA, A.M.T., SILVA, G.R. \& CARVALHO-E-SILVA, S.P. 2008 Anurans at Rio das Pedras Reserve, Mangaratiba, RJ, Brazil. Biota Neotrop. 8(1): 199-209. http://www.biotaneotropica. org.br/v8n1/en/abstract?inventory +bn02608012008 (last access on 06/11/2017)

COLLI, G.R., BASTOS, R.P. \& ARAUJO, A.F.B. 2002. The character and dynamics of the Cerrado herpetofauna. In The Cerrados of Brazil: ecology and natural history of a neotropical savanna (P.S. Oliveira \& R.J. Marquis, eds). Columbia University Press, New York, p.223-239.

COLWELL, R.K. 2006. EstimateS: Statistical estimation of species richness and shared species from samples. Version 8.0. http://purl.oclc.org/estimates. (last access on $02 / 08 / 2017$ ). 
CONCEIÇÃO, G.M. \& CASTRO, A.A.J.F. 2009. Fitossociologia de uma área de Cerrado Marginal, Parque Estadual do Mirador, Mirador, Maranhão. Scien. Plena. 5(10): 1-16.

DAL VECHIO, F., RECODER, R., RODRIGUES, M.T. \& ZAHER, H. 2013. The herpetofauna of the Estação Ecológica de Uruçuí-Una, state of Piauí, Brazil. Pap. Avulsos Zool. 53(16): 225-243.

DIAS, I.R., MEDEIROS, T.T., VILA NOVA, M.F. \& SOLÉ, M. 2014. Amphibians of Serra Bonita, southern Bahia: a new hotpoint within Brazil's Atlantic Forest hotspot. ZooKeys. 449: 105-130.

DINIZ-FILHO, J.A.F., BINI, L.M., VIEIRA, C.M., SOUZA, M.C., BASTOS, R.P., BRANDÃO, D. \& OLIVEIRA, L.G. 2004. Spatial patterns in species richness and priority areas for conservation of anurans in the Cerrado region, Central Brazil. Amphibia-Reptilia. 25: 63-75.

DINIZ-FILHO, J.A.F., BASTOS, R.P., RANGEL, T.F.L.V.B., BINI, L.M., CARVALHO, P. \& SILVA, R.J. 2005a. Macroecological correlates and spatial patterns of anuran description dates in the Brazilian Cerrado. Global Ecol. Biogeogr. 14(5): 469-477.

DINIZ-FILHO, J.A.F., BINI, L.M., BASTOS, R.P., VIEIRA, C.M. \& VIEIRA, L.C.G. 2005b. Priority areas for anuran conservation using biogeographical data: a comparison of greedy, rarity, and simulated annealing algorithms to define reserve networks in Cerrado. Braz. J. Biol. 65: 251-261.

DÓRIA, T.A.F., KLEIN, W., ABREU, R.O., SANTOS, D.C., CORDEIRO, M.C., SILVA, L.M., VANESSA MARCELO, M.G.B. \& NAPOLI, F. 2015. Environmental Variables Influence the Composition of Frog Communities in Riparian and Semi-Deciduous Forests of the Brazilian Cerrado. South Am. J. Herpetol. 10(2): 90-103.

FORLANI, M.C., BERNARDO, P.H., HADDAD, C.F.B. \& ZAHER, H. 2010. Herpetofauna do Parque Estadual Carlos Botelho, São Paulo, Brasil. Biota Neotrop. 10(3): 265-309. http://www.biotaneotropica.org.br/v10n3/en/abstra ct?inventory+bn00210032010 (last access on 02/08/2017).

FREITAS, M.A., VIEIRA, R.S., ENTIAUSPE-NETO, O.M., SOUSA, S.O., FARIAS, T., SOUZA, A.G. \& MOURA, G.J.B. 2017. Herpetofauna of the Northwest Amazon forest in the state of Maranhão, Brazil, with remarks on the Gurupi Biological Reserve. ZooKeys. 643: 141-155.

FROST, D.R. Amphibian Species of the World: an Online Reference. Version 6.0. 2017. http://research.amnh.org/herpetology/amphibia/index.html. American Museum of Natural History, New York, USA. (last access on 06/11/2017)

GAMBALE, P.G., WOITOVICZ-CARDOSO, M., VIEIRA, R.R., BATISTA, V.G., RAMOS, J. \& BASTOS, R.P. 2014. Composição e riqueza de anfíbios anuros em remanescentes de Cerrado do Brasil Central. Iheringia, Sér. Zool. 104(1): 50-58.

GANEM, R.S. 2007. Políticas de conservação da biodiversidade e conectividade entre remanescentes de cerrado. 2007. 431 f., il. Tese (Doutorado em Desenvolvimento Sustentável) - Universidade de Brasília, Brasília.

GARDA, A.A., COSTA, T.B., SANTOS-SILVA, C.R., MESQUITA, D.O., FARIA, R.G., CONCEIÇÃO, B.M., SILVA, I.R.S., FERREIRA, A.S., ROCHA, S.M., PALMEIRA, C.N.S., RODRIGUES, R., FERRARI, S.F. \& TORQUATO, S. 2013. Herpetofauna of protected areas in the Caatinga I: Raso da Catarina Ecological Station (Bahia, Brazil). Check List. 9(2): 405-414.

GORDO, M. \& CAMPOS, Z. 2003. Listagem de anuros da Estação Ecológica Nhumirim e arredores, Pantanal Sul. Embrapa Pantanal, Corumbá, p.1-21.

GORDO, M. \& CAMPOS, Z. 2005. Anuros das Serras de Entorno do Pantanal Sul. Embrapa Pantanal, Corumbá, p.1-20.

GOTELLI, N.J. \& COLWELL, R.K. 2001. Quantifying biodiversity: procedures and pitfalls in the measurement and comparison of species richness. Ecol. Lett. 4(4): 379-391.

HAMMER, Ø., HARPER, D.A.T. \& RYAN, P.D. 2001. PAST: Paleontological Statistics Software Package for Education and Data Analysis. Palaeontol. Electr. 4(1): 9pp.

HEYER, W.R., DONNELLY, M.A., MCDIARMID, R.W., HAYEK, L.A.C. \& FOSTER, M.S. 1994. Measuring and monitoring biological diversity: standard methods for amphibians. Smithsonian Institution Press, Washington.

IBAMA. Unidades de Conservação. IBAMA, 2009. http://www.ibama.gov.br/ zoneamentoambiental/ucs/ (last access on 06/11/2017)
IBGE. Instituto Brasileiro de Geografia e Estatística. 2004. Mapa de biomas brasileiros. Rio de Janeiro: IBGE, Escala 1:5.000.000. http://mapas.ibge.gov. br/biomas2/viewer.htm (last access on 06/011/2017)

ILHA, P. \& DIXO, M. 2010. Anurans and Lizards, Rio Preto da Eva, Amazonas, Brazil. Check List. 6(1): 17-21.

IUCN. The IUCN Red List Treatened Species. 2012. Categories and Criteria: Version 3.1. Second edition. Gland, Switzerland and Cambridge, UK: IUCN. iv + 32pp. http://www.iucnredlist.org (last access on 06/11/2017)

JUNGFER, K.-H., FAIVOVICH, J., PADIAL, J.M., CASTROVIEJO-FISHER, S., LYRA, M.M., BERNECK, B.V.M., IGLESIAS, P.P., KOK, P.J.R., MACCULLOCH, R.D., RODRIGUES, M.T., VERDADE, V.K., TORRES GASTELLO, C.P., CHAPARRO, J.C., VALDUJO, P.H., REICHLE, S., MORAVEC, J., GVOZDÍK, V., GAGLIARDI-URRUTIA, G., ERNST, R., DE LA RIVA, I., MEANS, D.B., LIMA, A.P., SEÑARIS, J.C., WHEELER, W.C. \& HADDAD, C.F.B. 2013. Systematics of spiny-backed treefrogs (Hylidae: Osteocephalus): an Amazonian puzzle. Zool. Scripta. 42: 351-380.

KLINK, C.A. \& MACHADO, R.B. 2005. A conservação do Cerrado brasileiro. Megadiversidade 1: 148-155.

KNISPEL, S.R. \& BARROS, F.B. 2009. Anfíbios anuros da região urbana de Altamira (Amazônia Oriental), Pará, Brasil. Biotemas. 22(2): 191-194.

KOPP, K., SIGNORELLI, L. \& BASTOS, R.P. 2010. Distribuição temporal e diversidade de modos reprodutivos de anfíbios anuros no Parque Nacional das Emas e entorno, estado de Goiás, Brasil. Iheringia, Sér. Zool. 100(3): 192-200.

LIMA, A.P., MAGNUSSON, W.E., MENIN, M., ERDTMANN, L.K., RODRIGUES, D.J., KELLER, C. \& HÖDL, W. 2005. Guia de Sapos da Reserva Adolpho Ducke, Amazônia Central (Guide to the frogs of Reserva Adolpho Ducke, Central Amazonia). Áttema Design Editorial, Manaus.

LIMA, T.G.P., ANDRADE, E.B., ARAÚJO, K.C., LEITE, J.R.S.A. \& WEBER, L.N. 2015. First record of Leptodactylus sertanejo (Anura: Leptodactylidae: Leptodactylinae) in the state of Maranhão, northeastern Brazil. Check List. 11(5): 1776. doi: http://dx.doi.org/10.15560/11.5.1776

LOEBMANN, D. \& HADDAD, C.F.B. 2010. Amphibians and reptiles from a highly diverse area of the Caatinga domain: composition and conservation implications. Biota Neotrop. 10(3): 227-256. http://www.biotaneotropica.org.br/v10n3/en/ abstract?article+bn03910032010 (last access on 06/11/2017)

MAGURRAN, A.E. 2004. Measuring biological diversity. Oxford, Blackwell.

MALTCHIK, L., PEIXOTO, C.D., STENERT, C., MOREIRA, L.F.B. \& MACHADO, I.F. 2008. Dynamics of the terrestrial amphibian assemblage in a flooded riparian forest fragment in a Neotropical region in the south of Brazil. Braz. J. Biol. 68(4): 763-769.

MARANHÃO. Lei n ${ }^{\circ} 8.958$ de 08 de maio de 2009. Altera o Decreto ${ }^{\circ} 7.641 / 80$ de junho de 1980, que cria o Parque Estadual de Mirador e dá outras providências. São Luís: D.O.E, de 08.05.2009, Ano CIII, n. 087.

MATAVELLI, R., CAMPOS, A.M., MENDONÇA, M.A. \& ANDRADE, G.V. 2013. New records of anurans in the state of Maranhão, Brazil: Hypsiboas boans (Linnaeus, 1758) (Hylidae) and Leptodactylus syphax Bokermann, 1969 (Leptodactylidae). Check List. 9(4): 899-901.

MATAVELLI, R., CAMPOS, A.M., SILVA, G.R. \& ANDRADE, G.V. 2014. First record of Rhinella ocellata (Günther, 1858) (Bufonidae) for the state of Maranhão, northeastern Brazil. Check List. 10(2): 432-433.

MELO, M., FAVA, F., PINTO, H.B.A., BASTOS, R.P. \& NOMURA, F. 2013. Diversidade de anuros (Amphibia) na reserva extrativista Lago do Cedro e seu entorno, Aruanã, Goiás. Biota Neotrop. (13)2: 205-217. http://www. biotaneotropica.org.br/v13n2/en/abstract?inventory+bn02913022013 (last access on 06/11/2017)

MMA, Ministério do Meio Ambiente. 2007. Áreas Prioritárias para Conservação, Uso Sustentável e Repartição de Benefícios da Biodiversidade Brasileira: Atualização - Portaria nº 9, de 23 de janeiro de 2007. Brasília: MMA, 2007. (Série Biodiversidade, 31).

MMA, Ministério do Meio Ambiente. 2014. Portaria $n^{\circ}$ - 444, de 17 de dezembro de 2014. Lista nacional oficial de espécies da fauna ameaçadas de extinção. Brasília: D.O.U., de 17.12.2014, n 245, seção 1, p.121-126.

ODA, F.H., BASTOS, R.P. \& LIMA, M.A.C.S. 2009. Anuran assemblage in the Cerrado of Niquelândia, Goiás State, Brazil: diversity, local distribution and 
seasonality. Biota Neotrop. 9(4): 219-232. http://www.biotaneotropica.org. br/v9n4/en/abstract?inventory+bn03609042009 (last access on 06/11/2017)

PANSONATO, A., MOTT, T. \& STRÜSSMANN, C. 2011. Anuran amphibians' diversity in a northwestern area of the Brazilian Pantanal. Biota Neotrop. 11(4): 77-86. http://www.biotaneotropica.org.br/v11n4/en/ abstract?article+bn01711042011 (last access on 06/11/2017)

PANTOJA, D.L. \& FRAGA, R. 2012. Herpetofauna of the Reserva Extrativista do Rio Gregório, Juruá Basin, southwest Amazonia, Brazil. Check List. 8(3): 360-374

PEDROSA, I.M.M.C., COSTA, T.B., FARIA, R.G., FRANÇA, F.G.R., LARANJEIRAS, D.O., OLIVEIRA, T.C.S.P., PALMEIRA, C.N.S., TORQUATO, S., MOTT, T., VIEIRA, G.H. C. \& GARDA, A.A. 2014. Herpetofauna of protected areas in the Caatinga III: The Catimbau National Park, Pernambuco, Brazil. Biota Neotrop. 14(4): http://dx.doi.org/10.1590/1676-06032014004614 (last access on $06 / 11 / 2017$ )

POMBAL-JR., J.P. 1995. Biologia reprodutiva de anuros (Amphibia) associados a uma poça permanente na Serra de Paranapiacaba, sudeste do Brasil. Tese de doutorado, Universidade Estadual Paulista, Rio Claro.

RIBEIRO, J.F. \& WALTER, B.M.T. 2008. As principais fitofisionomias do Bioma Cerrado. In Cerrado: ecologia e flora (S.M. Sano, S.P. Almeida \& J.F. Ribeiro, eds.). Embrapa Cerrados, Planaltina. p. 151-212.

RIBEIRO, S.C., ROBERTO, I.J., SALES, D.L., ÁVILA, R.W. \& ALMEIDA, W.O 2012. Amphibians and reptiles from the Araripe bioregion, northeastern Brazil Salamandra, 48(3): 133-146.

RIBEIRO-JÚNIOR, J.W. \& BERTOLUCI, J. 2009. Anurans of the cerrado of the Estação Ecológica and the Floresta Estadual de Assis, southeastern Brazil Biota Neotrop. 9(1): 207-216. http://www.biotaneotropica.org.br/v9n1/en/abs tract?inventory+bn02709012009 (last access on 06/11/2017)

ROBERTO, I.J., RIBEIRO, S.C. \& LOEBMANN, D. 2013. Amphibians of the state of Piauí, Northeastern Brazil: a preliminary assessment. Biota Neotrop. 13(1): 322-329. http://www.biotaneotropica.org.br/v13n1/ pt/abstract?invento ry+bn04113012013 (last access on 06/11/2017)

RODRIGUES, M.T. 2005. A biodiversidade dos Cerrados: conhecimento atual e perspectivas, com uma hipótese sobre o papel das matas galerias na troca faunística durante ciclos climáticos. In Cerrado: ecologia, biodiversidade e conservação (A. Scariot, J.C.S. Silva, \& J.M. Felfili, Coord.). Ministério do Meio Ambiente, Brasília, p.235-246.

SANTANA, G.G., VIEIRA, W.L.S., PEREIRA-FILHO, G.A., DELFIM, F.R., LIMA, Y.C.C. \& VIEIRA, K.S. 2008. Herpetofauna em um fragmento de Floresta Atlântica no Estado da Paraíba, Região Nordeste do Brasil. Biotemas. 21(1): 75-84.

SANTORO, G.R.C.C. \& BRANDÃO, R.A. 2014. Reproductive modes, habitat use, and richness of anurans from Chapada dos Veadeiros, central Brazil. NorthWestern J. Zool. 10(2): 365-373.
SANTOS, D.L., ANDRADE, S.P., VICTOR-JR., E.P. \& VAZ-SILVA, W. 2014 Amphibians and reptiles from southeastern Goiás, Central Brazil. Check List. 10(1): 131-148.

SÃO PEDRO, V.A. \& FEIO, R.N. 2011. Anuran species composition from Serra do Ouro Branco, southernmost Espinhaço Mountain Range, state of Minas Gerais, Brazil. Check List. 7(5): 671-680.

SILVA, J.M.C. \& BATES, J.M. 2002. Biogeograhic patterns and conservation in the South American Cerrado: a tropical savanna Hotspot. BioScience. 52: 225-233.

SILVA, R.A., MARTINS, I.A \& ROSSA-FERES, D.C. 2011. Environmental heterogeneity: Anuran diversity in homogeneous environments. Zool. 28(5): 610-618.

SILVA, A.S.F.L., SIQUEIRA JÚNIOR, S. \& ZINA, J. 2013. Checklist of amphibians in a transitional area between the Caatinga and the Atlantic Forest, centralsouthern Bahia, Brazil. Check List. 9(4): 725-732.

SILVA-LEITE, R.R., LEITE JÚNIOR, J.M.A., BARBOSA, E.A., NORONHA, S \& LEITE, J.R.S.A. 2008. The anurans of Terra Ronca State Park, municipality of São Domingos, State of Goiás, central Brazil. Sitientibus Série. Ciênc, Biol. 8(2): 162-167.

SOUZA, V.M., SOUZA, M.B. \& MORATO, E.F. 2008. Efeitos da sucessão florestal sobre a anurofauna (Amphibia: Anura) da Reserva Catuaba e seu entorno, Acre, Amazônia sul-ocidental. Rev. Bras. Zool. 25(1): 49-57.

UETANABARO, M., SOUZA, F.L., LANDGREF FILHO, P., BEDA, A.F. \& BRANDÃO, R. A. 2007. Anfíbios e répteis do Parque Nacional da Serra da Bodoquena, Mato Grosso do Sul, Brasil. Biota Neotrop. 7(3): 279-289. http:// www.biotaneotropica.org.br/v7n3/pt/abstract?inventory+bn01207032007 (last access on 06/11/2017)

VALDUJO, P.H., RECODER, R.S., VASCONCELLOS, M.M. \& PORTELLA, A.S 2009. Amphibia, Anura, São Desidério, western Bahia uplands, northeastern Brazil. Check List. 5(4): 903-911.

VALDUJO, P.H., CAMACHO, A., RECODER, R.S., TEIXEIRA JR, M., GHELLERE, J.M.B., MOTT, T., NUNES, P.M.S., NOGUEIRA, C. \& RODRIGUES, M. T. 2011. Anfíbios da Estação Ecológica Serra Geral do Tocantins, região do Jalapão, Estados do Tocantins e Bahia. Biota Neotrop. 11(1): 251-262. http:// www.biotaneotropica.org.br/v11n1/en/abstract?article+bn03511012011 (last access on $06 / 11 / 2017$ )

VIEIRA, W.L.S., ARZABE, C. \& SANTANA, G.G. 2007. Composição e distribuição espaço-temporal de anuros no Cariri paraibano, Nordeste do Brasil. Oecol. Bras. 11(3): 383-396. 